\title{
Diatoms in Paleoenvironmental Studies of Peatlands
}

\author{
Rafael Carballeira ${ }^{1, *(1)}$ and Xabier Pontevedra-Pombal ${ }^{2}$ \\ 1 Centro de Investigacións Científicas Avanzadas (CICA), Facultade de Ciencias, Universidade da Coruña, \\ 15071 A Coruña, Galicia, Spain \\ 2 Department of Soil Science and Agricultural Chemistry, Faculty of Biology, University of Santiago de \\ Compostela, 15782 Santiago de Compostela, Galicia, Spain; xabier.pombal@usc.es \\ * Correspondence: r.carballeira@udc.es or rafael.carballeira@gmail.com; Tel.: +34-981-167000
}

Received: 5 January 2020; Accepted: 15 March 2020; Published: 1 April 2020

\begin{abstract}
The great diversity of diatoms in aquatic ecosystems and their close relationship with water chemistry make them one of the most informative and widely used biological proxies in paleoenvironmental studies of wetlands, except for peatland ecosystems. Currently, significant controversy still exists over the preservation of diatoms in peat. However, considerable evidence indicates that diatoms remain in good condition in minerotrophic peatlands, and they have been successfully used in paleoenvironmental studies in high-latitude regions and especially in Southern Europe.
\end{abstract}

Keywords: diatoms; paleoecology; peatlands; Southern Europe

\section{Introduction}

Peatland ecosystems are highly sensitive to climatic conditions and anthropic pressure; therefore, they have been classified as a priority habitat of community interest by the Habitats Directive 92/43/EEC of the European Union [1], in order to establish protection areas and promote monitoring programs that guarantee their conservation. This situation, in the context of climate change, is especially concerning in Southern Europe, where their distribution is very limited and highly fragmented [2-4].

Peatlands are wetlands formed through a complex biogeochemical equilibrium that produces a positive balance in the formation of peat, as a result of the accumulation of mostly vegetal organic matter under anaerobic conditions due to water saturation [5]. The development of peatlands during the Holocene has been a global sink of $C$ large enough to have a significant impact on the overall $\mathrm{C}$ budget and changes in atmospheric $\mathrm{CO}_{2}$, despite representing only $3 \%$ of the earth's surface [6-10]. The conservation and restoration of peatlands in the current context of global change play a crucial role both in preventing peatland degradation that would cause the release of stored carbon to the atmosphere [11-14] and in the maintenance of the biodiversity associated with peatland ecosystems; however, for the latter purpose, reference conditions and human disturbances must be assessed through a paleoecological approach [12,15]. In fact, the continuous accumulation of peat for thousands of years provides one of the best records for landscape, paleoecological, and climate reconstruction studies [16,17].

In paleoenvironmental studies of peatlands, macroscopic plant remains and pollen are generally considered the best tracers among the different biological proxies preserved in peat because changes in vegetation are directly related to the formation of peat [18], and they are widely used in peatlands of Southern Europe [19-22]. Thecamoebians are also a common indicator often associated with Sphagnum: They are more sensitive to water conditions and show a faster response to environmental changes than vegetation $[23,24]$. Diatoms are one of the most widely used indicators in paleoenvironmental and current ecology studies in wetlands because they are highly sensitive to changes in water chemistry, $\mathrm{pH}$, and nutrient conditions; however, diatoms are only exceptionally used in peatlands $[25,26]$. For this 
reason, this paper focuses on the potential of diatoms in paleoenvironmental studies of peatlands reviewing the scarce and disperse information available in Europe and other regions of the world.

\section{Diatoms in Peatland Ecosystems}

Diatoms are one of the most ubiquitous and diverse photosynthetic microorganisms in aquatic ecosystems [27] and one of the most widely represented algal groups in peat bogs (e.g., [28-32]). The diversity of diatoms in the peatlands of Europe is very high, with around 403 recorded taxa, and a majority representation of the genera Pinnularia (14\%), Eunotia (10\%), and Navicula $(10 \%)$, with respect to the total number of taxa $[28,29,32-50]$, and with similar species numbers and compositions to those found in peatlands in other regions of the world due to the cosmopolitan nature of diatom species (e.g., [30,31,51,52]). However, knowledge about the ecology of diatom communities in peatlands is still insufficient compared with other types of wetlands [25].

Peatlands are very complex ecosystems, with a great diversity of microhabitats and spatial heterogeneity as a result of the discontinuous water availability, the distribution of vegetation, and small-scale chemical gradients [41]. Like vegetation, species richness of diatom communities decreases with the moisture and chemical gradient, from fen to bog [42,53]. Water availability, $\mathrm{pH}$, and ionic composition of water are the main factors in the distribution of diatom species in microhabitats and the composition of diatom communities in peatlands [29,31,44,52].

Moreover, bryophyte communities can govern the distribution of diatoms, since differences in leaf morphology and water retention capacity among Sphagnum species can condition water availability and, consequently, other chemical factors [54]. However, the composition and fluctuation of diatom communities are not necessarily associated with changes in bryophyte communities [42,55], unlike in the case of thecamoebians $[23,24]$.

Given that peats are shallow environments, their diatom communities are characterized by a low representation of diatoms of the order Centrales and/or planktonic diatoms, with greater representation of tychoplanktonic and/or epiphytic species, such as Tabellaria flocculosa, Fragilaria capucina, Staurosira construens, Stauroforma virescens, Gomphonema angustatum, Gomphoenma gracile, or Gomphonema paroulum [56]. The abundances of the different diatom taxa are consistent with water chemistry in peat bogs, with majority representation of taxa from acidophilic, halophobic, aerophilic, and oligotrophic environments [56] and particularly high representation and diversity of genera Eunotia and Pinnularia [43].

\section{Diatom Preservation in Peat}

The water source of the peatlands determines the chemistry of the water (i.e., water availability, the degree of mineralization, nutrient levels, and the $\mathrm{pH}$ of the water), so that three main types of peatlands can be established according to the origin of the water: (i) minerotrophic, exclusively runoff water; (ii) ombrotrophic, exclusively rainwater; and (iii) mixed, in the case of minerotrophic peatlands with vertically elevated ombrotrophic domes. The minerotrophic peatlands are a majority in Europe while the less frequent ombrotrophic peatlands are mainly distributed in the area of European Atlantic influence [57].

The current diatom communities in peatlands are abundant, but diatom thanatocoenosis in peat is still unknown, and its preservation is widely discussed. However, evidence suggests that the conservation status of diatom valves in paleoenvironmental records in minerotrophic peatlands is good [25]. The method generally used in the extraction of diatoms from peat is acid digestion (e.g., [58-61]), which was improved and standardized by Serieyssol et al. [62].

Patrick [58] examined the diatoms of the mixed Patschke bog peat deposits (Texas, TX, USA), and observed in the ombrotrophic part there are only a few poorly preserved remains of diatoms at some levels, but a greater abundance in the minerotrophic part with an acceptable degree of general conservation, although worse in the case of thinly silicified Frustulia valves, with highly fragmented and dissolved valves noted. Moreover, Kräckelbäcken mires (Dalarna, Sweden) are minerotrophic 
peatlands with a great abundance of diatoms and good state of preservation of the valves throughout the entire peat profile [63]. However, the poor conservation of post-burial diatom frustules in peat has been one of the main explanations for their absence or deterioration in the paleoenvironmental records from peatlands, as evidenced by rigorous studies on the peat bogs of Villaseca and La Mata (León, Spain) in the Iberian Peninsula [64,65]. The $\mathrm{pH}$ is considered the main factor that determines the redissolution of silica by complexing with organic acids (e.g., salicylic, oxalic, or humic acids); however, this chemical dissolution process follows the dissolution curve of silica occurring at basic-circumneutral $\mathrm{pH}$ ranges while falling sharply at acidic $\mathrm{pH}$ ranges [66,67]. Only alkaline (or calcareous) peat bogs formed on a bed of limestone rocks, with calcium-rich waters and buffered by the bicarbonate system, have $\mathrm{pH}$ ranges $>5.5$ to 9 , which are favorable for the dissolution of silica $[68,69]$; however, the knowledge about this minority typology is very poor, as there are no paleoenvironmental studies or diatom preservation data. In addition, other factors in combination with $\mathrm{pH}$ - such as oligotrophy, which involves low concentrations of dissolved silica and a high fragmentation, as it is a shallow environment-could favor redissolution of diatoms [53,65,70]. Pienitz [40] proposed an active role of bacteria in the redissolution of silica from diatoms frustules analogous to the mechanisms known in marine ecosystems [71-73], but there are no similar phenomena described in continental aquatic ecosystems especially at low $\mathrm{pH}$ ranges.

On the other hand, abundant empirical evidence from paleoenvironmental studies in minerotrophic bogs shows acceptable concentrations of highly preserved frustules in high-latitude minerotrophic bogs in America (e.g., [51,53,56,59,74,75]), Asia (e.g., [76-78]), and Europe (e.g., [63,79-81]), but also in Southern Europe, in several peatlands of the Aquitania Basin area [82], French Massif Central (France) [60,61,83,84], and Central Sredna Gora Mountains (Bulgaria) [85-87] (Table 1 and Figure 1). Exceptionally, peatlands at even lower latitudes in the Badda peak, of more than $4000 \mathrm{~m}$ altitude, of the high Ethiopian mountain have diatoms with a good state of conservation as to be used in paleoenvironmental studies [88].

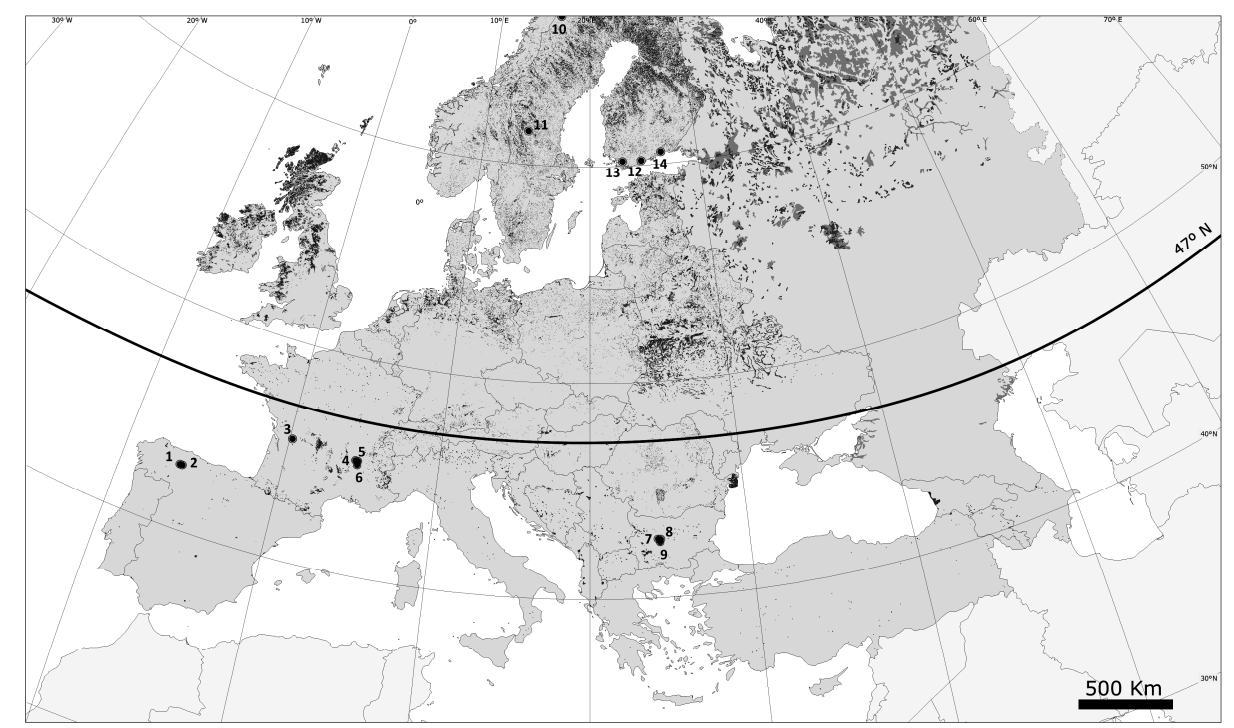

Figure 1. Distribution of peatlands in Europe, below the $47^{\circ} \mathrm{N}$ parallel the Southern Europe peatlands, in which diatoms have been used in paleoenvironmental reconstruction studies (see Table 1) (map modified from Tanneberg et al. [89]): (1) Villaseca; (2) La Mata; (3) Charente; (4) Le Verdier mire; (5) Virennes fens; (6) La Prenarde-Pifoy mire; (7) Bogdan-3; (8) Bogdan-6; (9) Shiligarka; (10) Stordalen mire; (11) Kräckelbäcken fen; (12) Reksuo; (13) Punassuo; (14) Munasuo. 
Table 1. List of peatlands in Europe, below the $47^{\circ} \mathrm{N}$ parallel the Southern Europe peatlands, in which diatoms have been used in studies of paleoenvironmental reconstruction.

\begin{tabular}{|c|c|c|c|c|c|c|c|c|}
\hline \multirow{2}{*}{ Peatlands } & \multirow{2}{*}{ Depth $(\mathrm{cm})$} & \multirow{2}{*}{ Years Cal BP } & \multirow{2}{*}{ Location } & \multicolumn{2}{|c|}{ Geographical Coordinates } & \multirow{2}{*}{$\begin{array}{l}\text { Altitude } \\
\text { (m.a.s.l.) }\end{array}$} & \multirow{2}{*}{ Country } & \multirow{2}{*}{ References } \\
\hline & & & & Latitude (N) & $\begin{array}{c}\text { Longitude } \\
\text { (W/E) }\end{array}$ & & & \\
\hline Villaseca fen & 65 & n.d. & Villablino (León, Spain) & $42^{\circ} 57^{\prime}$ & $6^{\circ} 16^{\prime}$ & 1320 & Spain & Leira et al. [64]; Leira [65] \\
\hline La Mata fen & n.d. & n.d. & Villablino (León, Spain) & $42^{\circ} 58^{\prime}$ & $6^{\circ} 13^{\prime}$ & 1500 & Spain & Leira et al. [64]; Leira [65] \\
\hline Charente & 500 & n.d. & $\begin{array}{c}\text { Valley of Boême, near } \\
\text { Mothiers-sur-Boëme (Charente, } \\
\text { France) }\end{array}$ & $45^{\circ} 36^{\prime}-45^{\circ} 31^{\prime}$ & $0^{\circ} 4^{\prime}-0^{\circ} 12^{\prime}$ & $125-150$ & France & Diot and Baudrimont [82] \\
\hline Le Verdier mire & 296 & $2231 \pm 251$ & $\begin{array}{l}\text { Saint-Jean-Soleymieux (Loire, } \\
\text { France) }\end{array}$ & $45^{\circ} 49^{\prime}-45^{\circ} 51^{\prime}$ & $3^{\circ} 45^{\prime}-3^{\circ} 52^{\prime}$ & 675 & France & Cubizolle et al. [61] \\
\hline Virennes fens & 176 & $3518 \pm 169$ & Puy-de-Dôme (Auvernia, France) & $45^{\circ} 31^{\prime}-45^{\circ} 32^{\prime}$ & $3^{\circ} 37^{\prime}-3^{\circ} 40^{\prime}$ & 1080 & France & Cubizolle et al. $[61,83]$ \\
\hline $\begin{array}{l}\text { La Prenarde-Pifoy } \\
\text { mire }\end{array}$ & 121 & $2485 \pm 50$ & $\begin{array}{c}\text { Saint-Jean-Soleymieux (Loire, } \\
\text { France) }\end{array}$ & $45^{\circ} 30^{\prime} 11^{\prime \prime}$ & $3^{\circ} 58^{\prime} 51^{\prime \prime}$ & 1125 & France & Cubizolle et al. [84] \\
\hline Bogdan-6 & 75 & $11622 \pm 956$ & $\begin{array}{c}\text { Koprivshtitsa (Sofia, Bulgaria), } \\
\text { Bogdan, Hisarya (Bogdan, } \\
\text { Bulgaria) }\end{array}$ & $42^{\circ} 36^{\prime}-42^{\circ} 33^{\prime}$ & $24^{\circ} 26^{\prime}-24^{\circ} 31^{\prime}$ & ca. 1400 & Bulgaria & Stancheva and Temniskova [87] \\
\hline Bogdan-3 & 140 & $9056 \pm 848$ & $\begin{array}{c}\text { Koprivshtitsa (Sofia, Bulgaria), } \\
\text { Bogdan, Hisarya (Bogdan, } \\
\text { Bulgaria) }\end{array}$ & $42^{\circ} 36^{\prime}-42^{\circ} 33^{\prime}$ & $24^{\circ} 26^{\prime}-24^{\circ} 31^{\prime}$ & 1400 & Bulgaria & Stancheva and Temniskova [87] \\
\hline Shiligarka & 60 & $6061 \pm 532$ & $\begin{array}{c}\text { Koprivshtitsa (Sofia, Bulgaria), } \\
\text { Bogdan, Hisarya (Bogdan, } \\
\text { Bulgaria) }\end{array}$ & $42^{\circ} 36^{\prime}-42^{\circ} 33^{\prime}$ & $24^{\circ} 26^{\prime}-24^{\circ} 31^{\prime}$ & ca. 1400 & Bulgaria & Stancheva and Temniskova [87] \\
\hline Stordalen mire & 80 & 1200 & $\begin{array}{c}\text { Stordalen mire (Norrbotten, } \\
\text { Sweden) }\end{array}$ & $68^{\circ} 21^{\prime}$ & $19^{\circ} 03^{\prime}$ & ca. 161 & Sweden & Kokfelt et al. [81] \\
\hline $\begin{array}{l}\text { Kräckelbäcken } \\
\text { mires }\end{array}$ & 400 & $6668 \pm 249$ & $\begin{array}{l}\text { Kräckelbäcken mires (Dalarna, } \\
\text { Sweden) }\end{array}$ & $61^{\circ} 30^{\prime}$ & $14^{\circ} 13^{\prime}$ & ca. 700 & Sweden & Foster and Fritz [63] \\
\hline Kotasuo bog & 530 & $2883 \pm 366$ & $\begin{array}{l}\text { Central part of Espoo parish } \\
\text { (Uusima, Finland) }\end{array}$ & $60^{\circ} 15^{\prime}$ & $24^{\circ} 35^{\prime}$ & n.d. & Finland & Korhola [79] \\
\hline Punassuo bog & 650 & $3729 \pm 327$ & $\begin{array}{c}\text { Perniö (Teijo) (Punassuo } \\
\text { (Southwest Finland, Finland) }\end{array}$ & $60^{\circ} 13^{\prime}$ & $23^{\circ} 02^{\prime}$ & n.d. & Finland & Korhola [80] \\
\hline Munasuo bog & 610 & $2404 \pm 374$ & Pyhtää (Kymenlaakso, Finland) & $60^{\circ} 34^{\prime}$ & $26^{\circ} 40^{\prime}$ & n.d. & Finland & Korhola [80] \\
\hline
\end{tabular}


Serieyssol et al. [62] established that the greater preservation of diatoms in minerotrophic peatlands than in ombrotrophic ones is the result of the greater redissolution of frustules at $\mathrm{pH}<5$. However, this explanation is contrary to the dissolution curve of silica in water as a function of $\mathrm{pH}[66,67,90]$, and current diatoms can survive in acidic peat environments even at a pH around 3 [30,41,52]. Differences in water availability between ombrotrophic- and minerotrophic-type peatlands can probably condition the amounts of diatoms on the surface; therefore, they can also condition the presence of diatoms incorporated into the peat. Consequently, ombrotrophic peatland development possibly leads to a decrease in diatoms associated with the increase in subaerial environment [74], specifically during dry periods [87]. The Mount Badda fen (Oromia, Ethiopia) shows alternating cycles of subaerial (ombrotrophic) and aquatic (minerotrophic) peat; these phases show a differential incorporation of diatoms into the peat. Subaerial phases show very low abundances of diatoms; moreover, diatom valves are more fragmented and partially dissolved, particularly smaller, thinly silicified valves [89]. However, some aspects of diatom preservation in peat are still unknown.

\section{Diatoms Paleoenvironmental Studies in Peatlands}

The presence of diatoms in peat is well-known but was not documented until 1969, by Diot and Baudrimont [82], and later in 1987, by Auer [91], in the first studies on the distribution of peat deposits in Canada. Diot and Baudrimont [82], from the Boëme Valley peat bog (Charente, France), showed a high sensitivity of diatoms to changes in water level, presumably the result of climatic changes in the rainfall regime, with greater abundance of total diatoms, diversity and proportion of (tycho-)planktonic diatoms (i.e., Ellerbeckia arenaria, Melosira varians, and Ulnaria ulna) in humid periods compared to dry periods, also concordant with the record of gastropod remains and pollen records. Diot and Baudrimont [82] suggested the potential of diatoms in the refinement of paleoenvironmental interpretations as paleoecological indicators of the peatland local conditions; this feature is also emphasized by recent authors $[60,61,64,87]$.

\subsection{Diatoms as Indicators of Human Impact on Peatlands}

The study of minerotrophic peatlands in the French Massif Central also emphasized the high sensitivity of diatoms to hydrological changes and the influence of land use in the basin on the wetland, especially for the refinement of the interpretation of pollen data $[59,60,80]$. According to archaeological data, the Le Verdier mire was originated from a semi-natural shallow wetland during the final Bronze Age and the first Iron Age, possibly to serve as a water reservoir for agricultural use. The peat bog initially developed at $2231 \pm 251$ years cal BP, as shown by complementary diatom and pollen profiles: the increase in (tycho-)planktonic diatom taxa (i.e., Aulacoseira distans and Aulacoseira italica) is associated with a decrease in arboreal pollen and an increase in pollen from aquatic plants, cereals, and crops. This evidence indicates an increase in water level in periods of enhanced agricultural activity [60].

Moreover, the Virennes fen and the La Prenarde-Pifoy mire evidence the great impact of agriculture on fragile oligotrophic peatland ecosystems and the high sensitivity of diatoms to slight changes in nutrient levels $[60,61]$. The Virennes fen formed at $3518 \pm 169$ years cal BP, also with important changes in diatom communities due to an increase in nutrient input and a decrease in water level, which was caused by increasing agricultural activity in the basin. As a result, diatom assemblages in lower levels, with a diversity of acidophilic and oligotrophic diatom taxa typical of peatlands (i.e., Eunotia paludosa, Eunotia spp., Pinnularia spp., and T. flocculosa), were replaced by eutrophic diatom taxa, which are also present in mineral soils (i.e., Nitzschia terrestris, Fragilaria capucina, and Sellaphora pupula) between $558 \pm 41$ and $184 \pm 24$ years cal BP [61].

The La Prenarde-Pifoy mire formed at $2485 \pm 50$ years cal BP, with a diatom community mainly dominated by genera Pinnularia and Eunotia, acidophilic and oligotrophic diatoms typical of peatlands, with a high proportion of epiphytes (i.e., Cocconeis placentula and Gomphonema spp.) and with the presence of planktonic forms of the genus Aulacoseira, both groups indicative of a shallow wetland. 
However, the increase in agricultural activity between 2400 and 2000 years cal BP, as indicated by cereal and crop pollen records, led to an increase in nutrients in the wetland, causing drastic changes in the diatom community, with a decrease in diversity, a marked increase in meso-eutrophic diatoms (i.e., Cocconeis placentula, Fragilaria capucina, Staurosira construens, Fragilarioforma virescens, and Ulnaria ulna), and an increase in planktonic diatoms (i.e., Aulacoseira alpigena and A. distans) [84].

\subsection{Diatoms as Indicators of Long-Term Change in Peatlands}

Rühland et al. [76] provided a more complete reconstruction of the peatland succession based on the multiproxy paleoecological study of Siberian Arctic peat bogs, using diatoms as best indicators of hydrological and local conditions of the peat bog, as has also been recently recognized in similar studies on peatlands in Northwestern China [78].

Stancheva and Temniskova [87] demonstrated the high specificity of diatoms in peatland environments, with their ecological succession reflecting hydrological changes caused by regional climatic changes. The two Bogdan peatlands of the Sredna Central Mountains (Bulgaria) show the same paleoecological evolution, with pioneer peatland diatom flora occurring between $9056 \pm 28$ years cal BP (Bogdan-3) and $8742 \pm 1392$ years cal BP (Bogdan-6); the same process can be observed in Shiligarka, although later than in the former ones (6061 \pm 532 years cal BP). A long period of drought or decrease in annual rainfall during the mid-Holocene period, as indicated by other records in Southern Europe [92], interrupted the formation of peat and led to a decrease in the abundance of diatoms in the peat. The final stage in the three peat bogs corresponds to a wet period due to the new peat formation, with an increase in diatoms and a high diversity of diatom assemblages in the peat. The Bogdan and Shiligarka peatlands (Sredna Gora Mountains, Bulgaria) have aerophilic, acidophilic, and oligotrophic diatom taxa that are typical of peatlands, and the taxa found in the sedimentary record are very similar among all the peatlands, with a dominance of genera Eunotia (i.e., Eunotia glacialis, Eunotia serra, Eunotia steineckei, and Eunotia monodon), Pinnularia (i.e., Pinnularia subcapitata, Pinnularia appendiculata), Frustulia, and Stenopterobia; a fluctuating representation of planktonic or aerophilic diatoms, such as Aulacoseira alpigena or Hantzschia amphioxys, respectively; and a progressive growth of the diatoms:chrysophycean cysts ratio [87].

Kräckelbäcken mires (Dalarna, Sweden) are minerotrophic peatlands formed at $6668 \pm 249$ years cal BP, on a granitic rock bed. Peat composition has four phases of development as a result of the ecological succession of the vegetation associated with an increase in water level. Diatom communities show great specificity to water level but are also closely related with the main changes in vegetation. A short initial phase dominated by Sphagnum and Eunotia minor is followed by a second phase with greater bryophyte diversity and with the dominant diatom Aulacoseira nygaardii, which is indicative of higher water levels. The third and fourth phases are submerged and subaerial areas of the mires, respectively. The third phase is a submerged area with low incorporation of vegetation into the peat and an increase in the following diatom species: Eunotia parallela, Eunotia triodon, Tabellaria quadriseptata, Kobayasiella subtilissima, and Pinnularia abaujensis. The fourth phase is a subaerial area dominated by sedge vegetation and by the following species of diatoms: Eunotia exigua, Eunotia lapponica, Eunotia trinacria var. undulata, and Pinnularia rupestris. The species Eunotia denticulata and Pinnularia rupestris are also dominant in the last two phases [63].

The paleoecological succession of the Le Fleuve (i) and Rivière-du-Loup (ii) peat bogs in the lower Saint Lawrence River (Bas-Saint-Laurent, QC, Canada) shows a high specificity and sensitivity of diatom assemblages to microhabitats and to the peatlands' natural succession, despite the existence of small environmental differences and the poor diversity of diatom taxa in peatlands. The diatom assemblage sequence in the Le Fleuve (i) peat bog shows the progressive clogging of a shallow aquatic system and the subsequent minerotrophic peat-bog formation. This change is characterized by the replacement of predominantly aquatic diatom taxa, such as Cymbella aspera and Pinnularia streptoraphe; and by acidic and aerophilic diatom taxa typical of peatlands, such as Eunotia paludosa, Pinnularia subcapitata, and Pinnularia aff. hilseana, accompanied by H. amphioxys as an aerophilic soil species [59]. 
Moreover, Cubizolle et al. [60] and Leira et al. [64], in European minerotrophic peatlands, described analogous drastic changes in diatom assemblages during the progression from a lake environment, with the predominance of planktonic diatoms (i.e., Aulacoseira spp.), tychoplanktonic fragilarioid diatoms (i.e., Pseudostaurosira brevistriata, Staurosira construens, Staurosirella pinnata), and epiphytic Gomphonema species (i.e., Gomphonema parvulum, Gomphonema affine), to the origin and formation of a peat bog, with dominance of diatom taxa Pinnularia spp. and Frustulia spp. and with the increase of Eunotia spp.

The Rivière-du-Loup (ii) peat-bog diatom assemblage shows the evolution of the peat bog toward a greater degree of ombrotrophy, characterized by the decreasing diversity of an assemblage dominated by Eunotia tenella, E. paludosa, Frustulia saxonica, and Pinnularia borealis and with the presence of $H$. amphioxys, which were replaced by an almost monospecific dominance of E. paludosa, an indicator of oligotrophy and long drought periods in Sphagnum peat bogs. However, Lortie [59] mentioned as main limitations of diatoms the absence of adequate transfer functions in peatlands, their distribution in microhabitats, and the absence of knowledge about species autoecology, which remains poorly studied to this day (e.g., $[29,31,50])$.

The Mount Badda fen (Oromia, Ethiopia) is a minerotrophic peat bog formed at $11418 \pm 557$ years cal BP, in a glacier over-excavation on a basaltic rock bed. The diatom sequence along the profile shows two regularly alternating phases (subaerial/aquatic), closely related to cyclic fluctuations in the rainfall regime. The subaerial phase, although poor in diatoms, is dominated by diatoms indicative of ombrotrophic conditions (i.e., wet, low $\mathrm{pH}$, and oligotrophy), such as Aulacoseira distans, Eunotia praerupta, Eunotia pectinalis, Pinnularia borealis, Diploneis smithii, Diploneis elliptica, and Diploneis pseudovalis. The aquatic phase is dominated by tychoplanktonic diatoms indicative of minerotrophic conditions (i.e., higher water levels, low to circumneutral $\mathrm{pH}$, and mesotrophy), such as Pseudostaurosira brevistriata, Staurosira construens, Staurosira pinnata, and Staurosirella pinnata [89].

\section{Conclusions}

Diatoms have been proven to be a valuable tool as paleoecological or paleoenvironmental indicators in minerotrophic peatlands that should be more commonly applied to paleoecological studies of peatlands, with considerable abundances and an optimum degree of preservation of valves in peat. On the contrary, the abundance and preservation of diatoms in the paleoenvironmental records of ombrotrophic peatlands is very poor; possibly, the lower availability of water prevents the abundance and incorporation of diatoms into the peat, although the causes of this differential conservation, depending on the type of peatlands, are still unknown. However, diatoms have a great potential for the study of peatlands because, although they are not useful in ombrotrophic peats, minerotrophic peatlands are the most widely represented type.

The diatoms are widely represented in all types of peatlands, they are highly diverse, and their taxonomy is well-known. Water availability, $\mathrm{pH}$, and chemical composition of water are the main factors that determine the composition of diatom communities, so they constitute good (paleo)ecological indicators of great sensitivity to local or environmental changes (e.g., water level, rainfall regime, vegetation ecological succession, and human disturbances), although the distribution of species and their autoecology in peatland microhabitats are still poorly known.

Thus, diatoms can be an important tool for assessing and monitoring the conservation status of peatlands from a paleoecological standpoint in Europe, a continent whose landscape has been highly transformed by agriculture and has suffered great anthropogenic pressure for millennia, and especially in Southern Europe, where the balance allowing for active peat formation and peatland conservation is more fragile in the current climate-change scenario.

Finally, one of the main limitations to the study of peatlands is the high complexity of this ecosystem, since there is no widely accepted definition of peatland, and their description and paleoenvironmental records are usually incomplete, which prevents the establishment of adequate comparisons. 
Author Contributions: Conceptualization, X.P.-P. and R.C.; investigation, R.C. and X.P.-P.; writing-original draft preparation, R.C. and X.P.-P.; writing-review and editing, R.C.; supervision, X.P.-P. All authors have read and agreed to the published version of the manuscript.

Funding: This research was made possible through receipt of a grant awarded by the Xunta de Galicia (project: INCITE09-200-019-PR) and through the support for "Consolidación e Estructuración 2018 GRC GI-1243-GEMAP, ED431C 2018/32". The Ministerio de Economía y Competitividad del Gobierno de España funded this research through the project PaleoMODES (CGL2016-75281-C2-1-R). Rafael Carballeira is grateful for a Ph.D. fellowship from the Xunta de Galicia (Plan I2C) co-financed by European Social Fund.

Acknowledgments: We thank the reviewers who made constructive suggestions for improving the manuscript.

Conflicts of Interest: The authors declare no conflict of interest.

\section{References}

1. European Commission. European Commission Interpretation Manual of European Union Habitats, Vers. EUR28; European Commission, DG Environment: Brussel, Belgium, 2013.

2. Pontevedra-Pombal, X.; Castro, D.; Carballeira, R.; Souto, M.; López-Sáez, J.A.; Pérez-Díaz, S.; Fraga, M.I.; Valcárcel, M.; García-Rodeja, E. Iberian acid peatlands: Types, origin and general trends of development. Mires Peat 2017, 19, 1-19.

3. Joosten, H. Mires in Europe: A preliminary status report. Int. Mire Conserv. Group Memb. Newslett. 1997, 3, $10-13$.

4. Heras-Pérez, P.; Infante-Sánchez, M.; Pontevedra-Pombal, X.; Nóvoa-Muñoz, J.C. Part II, Country chapters: Spain. In Mires and Peatlands of Europe; Joosten, H., Tanneberger, F., Moen, A., Eds.; Schweizerbart Science Publishers: Sttutgart, Germany, 2017; pp. 639-656.

5. Mäkila, M.; Saarnisto, M. Carbon accumulation in boreal peatlands during the holocene-Impcts of climate variations. In Peatlands and Climate Change; Strack, M., Ed.; International Peat Society: Jyväskylä, Finland, 2008; pp. 24-43.

6. Yu, Z.C.; Loisel, J.; Brosseau, D.P.; Beilman, D.W.; Hunt, S.J. Global peatland dynamics since the Last Glacial Maximum. Geophys. Res. Lett. 2010, 37, L13402. [CrossRef]

7. Page, S.E.; Rieley, J.O.; Banks, C.J. Global and regional importance of the tropical peatland carbon pool. Glob. Chang. Biol. 2011, 17, 798-818. [CrossRef]

8. Loisel, J.; Yu, Z.; Beilman, D.W.; Camill, P.; Alm, J.; Amesbury, M.J.; Anderson, D.; Andersson, S.; Bochicchio, C.; Barber, K.; et al. A database and synthesis of northern peatland soil properties and Holocene carbon and nitrogen accumulation. Holocene 2014, 24, 1028-1042. [CrossRef]

9. Dargie, G.C.; Lewis, S.L.; Lawson, I.T.; Mitchard, E.T.A.; Page, S.E.; Bocko, Y.E.; Ifo, S.A. Age, extent and carbon storage of the central Congo Basin peatland complex. Nature 2017, 542, 86-90. [CrossRef]

10. Leifeld, J.; Menichetti, L. The underappreciated potential of peatlands in global climate change mitigation strategies. Nat. Commun. 2018, 9, 1071. [CrossRef]

11. Similä, M.; Aapala, K.; Penttinen, J. Ecological Restoration in Drained Peatlands—Best Practices from Finland; Metsähallitus Natural Heritage Services: Helsinki, Finland, 2014; pp. 1-87.

12. Abdalla, M.; Hastings, A.; Truu, J.; Espenberg, M.; Mander, U.; Smith, P. Emissions of methane from northern peatlands: A review of management impacts and implications for future management options. Ecol. Evol. 2016, 6, 7080-7102. [CrossRef]

13. Wilson, D.; Blain, D.; Couwenberg, J.; Evans, C.D.; Murdiyarso, D.; Page, S.E.; Renou-Wilson, F.; Rieley, J.O.; Sirin, O.; Strack, M.; et al. Greenhouse gas emission factors associated with rewetting of organic soils. Mires Peat 2016, 17, 4 .

14. Pontevedra-Pombal, X.; Castro, D.; Souto, M.; Fraga, I.; Blake, W.H.; Blaauw, M.; López-Sáez, J.A.; Pérez-Díaz, S.; Valcárcel, M.; García-Rodeja, E. 10,000 years of climate control over carbon accumulation in an Iberian bog (southwestern Europe). Geosci. Front. 2019, 10, 1521-1533. [CrossRef]

15. Minayeva, Y.Y.; Bragg, O.M.; Sirin, A.A. Towards ecosystem-based restoration of peatland biodiversity. Mires Peat 2017, 19, 1-36.

16. Martínez-Cortizas, A.; Pontevedra-Pombal, X.; García-Rodeja, E. Mercury in a Spanish peat bog: Archive of climate change and atmospheric metal deposition. Science 1999, 284, 939-942. [CrossRef] [PubMed] 
17. Charman, D. Peatlands and Environmental Change; John Wiley and Sons: Chichester, UK, 2002; p. 312.

18. Mauquoy, D.; Van Geel, B. Plant macrofossil methods and studies: Mire and peat macros. In Encyclopedia of Quaternary Science; Elias, S.A., Ed.; Elsevier Science: Amsterdam, The Netherlands, 2007; pp. 2315-2336.

19. Castro, D.; Souto, M.; Garcia-Rodeja, E.; Pontevedra-Pombal, X.; Fraga, M.I. Climate change records between the mid and late Holocene in a peat bog from Serra do Xistral (SW Europe) using plant macrofossils and peat humification analyses. Palaeogeogr. Palaeoclimatol. Palaeoecol. 2015, 420, 82-95. [CrossRef]

20. Souto, M.; Castro, D.; Pontevedra-Pombal, X.; Garcia-Rodeja, E.; Fraga, M.I. Characterisation of Holocene plant macrofossils from North Spanish ombrotrofic mires: Vascular plants. Mires Peat 2016, 18, 1-21.

21. Souto, M.; Castro, D.; Pontevedra-Pombal, X.; Garcia-Rodeja, E.; Fraga, M.I. Characterisation of Holocene plant macrofossils from North Spanish ombrotrofic mires: Bryophytes. Mires Peat 2017, 19, 1-12.

22. Souto, M.; Castro, D.; García-Rodeja, E.; Pontevedra-Pombal, X. The use of plant macrofossils for Paleoenvironmental reconstructions in Southern European Peatlands. Quaternary 2019, 2, 34. [CrossRef]

23. Mitchell, E.A.D.; Buttler, A.J. Ecology of testate amoebae (Protozoa: Rhizopoda) in Sphagnum peatlands in the Jura mountains, Switzerland and France. Ecoscience 1999, 6, 565-576. [CrossRef]

24. Mitchell, E.A.D. Testate amoebae analysis in ecological and paleoecological studies of wetlands: Past, present and future. Biodivers. Conserv. 2008, 17, 2115-2137. [CrossRef]

25. Gaiser, E.; Rühland, K. Diatoms as indicators of environmental change in a wetlands and peatlands. In The Diatoms: Applications for the Environmental and Earth Sciences; Smol, J.P., Stoermer, E.F., Eds.; Cambridge University Press: Cambridge, UK, 2010; Chapter 25; pp. 473-496.

26. Battarbee, R.W. Diatom analysis. In Handbook of Holocene Palaeoecology and Palaeohydrology; Berglund, B.E., Ed.; John Wiley \& Sons: Chichester, UK, 1986; pp. 527-570.

27. Round, F.E.; Crawford, R.M.; Mann, D.G. The Diatoms: Biology and Morphology of the Genera; Cambridge University Press: Cambridge, UK, 1990; p. 760.

28. Piatek, J. Algae of the peat bog in Modlniczka near Kraków. Pol. Bot. Stud. 2007, 24, 1-74.

29. Fránková, M.; Bojková, J.; Poulíčková, A.; Hájek, M. The structure and species richness of the diatom assemblages of the Western Carpathian spring fens along the gradient of mineral richness. Fottea 2009, 9, 355-368. [CrossRef]

30. Kulikovskiy, M.S.; Lange-Bertalot, H.; Witkowski, A.; Dorofeyuk, N.I.; Genkal, S.I. Diatom Assemblages from Sphagnum Bogs of the World. I. Nur Bog in Northern Mongolia; Bibliotheca Diatomologica 55; J. Cramer: Stuttgart, Germany, 2010; p. 326.

31. Chen, X.; Bu, Z.; Stevenson, M.A.; Cao, Y.; Zeng, L.; Qin, B. Variations in diatom communities at genus and species levels in peatlands (central China) linked to microhabitats and environmental factors. Sci. Total Environ. 2016, 568, 137-146. [CrossRef] [PubMed]

32. Fussey, M.P. Contribution à la flore algologique du Jura. I. La florule algologique de la tourbière de Frasne (Doubs). Rev. Gen. Bot. 1948, 55, 338-359. (In French)

33. Margalef, R. Comunidades bióticas de las aguas dulces del noroeste de España. Publ. Inst. Biol. Apl. 1955, 21, 137-171. (In Spanish)

34. Margalef, R. Algas de agua dulce del noroeste de España. Publ. Inst. Biol. Apl. 1956, 22, 43-152. (In Spanish)

35. de Graaf, F. The microflora and fauna of a quaking bog in the nature reserve "Het Hol" near Kortenhoef in the Netherlands. Hydrobiologia 1957, 9, 210-217. [CrossRef]

36. Hayward, J. The periodicity of diatoms in Bogs. J. Ecol. 1957, 45, 947-954. [CrossRef]

37. Wuthrich, M.; Matthey, W. Les diatomées de la tourbière du Cachot (Jura neuchatelois). I. Étude systématique. Bull. Soc. Neuchatel. Sci. Nat. 1977, 100, 45-60. (In French)

38. Wuthrich, M.; Matthey, W. Les diatomées de la tourbière du Cachot (Jura suisse). II. Association et distribution des espèces caractéristiques. Schweiz. Z. Hydrol. 1978, 40, 87-103. (In French)

39. Pérez, C.; Castillo, P.M. Dinámica de la comunidad fitoplanctónica de una laguna somera (Padul, Granada). Sci. Gerund. 1990, 16, 99-112. (In Spanish)

40. Pienitz, R. Analyse des microrestes végétaux: Diatomées. In Écologie des Tourbières du Québec-Labrador; Payette, S., Rochefort, L., Eds.; Les Presses de 1’Université Laval: Quebec, QC, Canada, 2001; pp. 311-326. (In French)

41. Nováková, S. Algal flora of subalpine peat bog pools in the Krkonose Mts. Preslia 2002, 74, 45-56. 
42. Poulickova, A. Distribution of diatoms and bryophytes on linear transects through spring fens. Nova Hedwigia 2004, 78, 411-424. [CrossRef]

43. Buczkó, K.; Wojtal, A. Moss inhabiting siliceous algae from Hungarian peat bogs. Studia Bot. Hung. 2005, 36, 21-42.

44. Kulikovskiy, M.S. The species composition and distribution of diatoms in Sphagnum bogs of European Russia: Ecosystems of the Volga upland. Inland Water Biol. 2008, 1, 347-355. [CrossRef]

45. Kapetanovic, T.; Jahn, R.; Redzic, S.; Caric, M. Diatoms in a poor fen of Bijambare protected landscape, Bosnia and Herzegovina. Nova Hedwigia 2011, 93, 125-151. [CrossRef]

46. Neustupa, J.; Veselá, J.; Stástný, J. Differential cell size structure of desmids and diatoms in the phytobenthos of peatlands. Hydrobiologia 2013, 709, 159-171. [CrossRef]

47. Cambra, J. Micro-scale distribution of algae in a Pyrenean peat-bog, Spain. Hidrobiológica 2015, 25, $213-222$.

48. Mogna, M.; Cantonati, M.; Andreucci, F.; Angeli, N.; Berta, G. Diatom communities and vegetation of springs in the south-western Alps. Acta Bot. Croat. 2015, 74, 265-285. [CrossRef]

49. Vidakovic, D.; Krizmanic, J.; Sovran, S.; Cvijan, M. Diatoms from a peat bog on the Pester Plateau (Southwestern Serbia): New records for diatom flora of Serbia. Arch. Biol. Sci. 2016, 68, 107-116. [CrossRef]

50. Muntinová, P.T.; Kulichová, J.; Ugland, K.I. Temporal and spatial dynamics of diatom (Bacillariophyceae) communities in a peatland area. Cryptogam. Algol. 2017, 38, 253-266. [CrossRef]

51. Brugam, R.B.; Swain, P. Diatom indicators of peatland development at Pogonia Bog, Pond Minnesota, USA. Holocene 2000, 10, 453-464. [CrossRef]

52. Hargan, K.E.; Rühland, K.M.; Paterson, A.M.; Finkelstein, S.A.; Holmquist, J.R.; MacDonald, G.M.; Keller, W.; Smol, J.P. The influence of water-table depth and $\mathrm{pH}$ on the spatial distribution of diatom species in peatlands of the Boreal Shield and Hudson Plains, Canada. Botany 2015, 93, 57-74. [CrossRef]

53. Kingston, J.C. Association and distribution of common diatoms in surface samples from northern Minnesota peatlands. Nova Hedwigia 1982, 73, 333-346.

54. Poulí̌ková, A.; Hájková, P.; Kintrová, K.; Batková, R.; Czudková, M.; Hájek, M. Tracing decadal environmental change in ombrotrophic bogs using diatoms from herbarium collections and transfer functions. Environ. Pollut. 2013, 179, 201-209. [CrossRef] [PubMed]

55. Brown, K.M.; Douglas, M.S.V.; Smol, J.P. Siliceous microfossils in a Holocene, High Arctic peat deposit (Nordvesto, northern Greenland). Can. J. Bot. 1994, 72, 208-216. [CrossRef]

56. Van Dam, H.; Mertens, A.; Sinkeldam, J. A coded checklist and ecological indicator values of freshwater diatoms from the Netherlands. Neth. J. Aquat. Ecol. 1994, 28, 117-133.

57. Joosten, H.; Tanneberger, F.; Moen, A. Mires and Peatlands of Europe: Status Distribution and Conservation; Schweizerbart Science Publishers: Stuttgart, Germany, 2017; p. 780.

58. Patrick, R. Diatoms from Patschke Bog, Texas. In Notulae Naturae of the Academy of Natural Sciences of Philadelphia Number 170; The Academy of Natural Sciences: Philadelphia, PA, USA, 1946.

59. Lortie, G. Les diatomées fossiles de deux tourbières ombrotrophes du Bas-Saint-Laurent, Québec. Geogr. Phys. Quater. 1983, 37, 159-177. (In French) [CrossRef]

60. Cubizolle, H.; Georges, V.; Latour, C.; Argant, J.; Serieyssol, K. La turfigenèse à la fin du subboréal et au subatlantique dans les tourbières basses du Massif Central Oriental granitique (France): Une manifestation de l'action humaine? Quaternaire 2004, 15, 343-359. (In French) [CrossRef]

61. Cubizolle, H.; Serieyssol, K.; Argant, J. Diatom and pollen evidence of Holocene vegetation dynamics and human impact on the Virennes fenland (French Massif Central). Diatom Res. 2005, 20, 257-273. [CrossRef]

62. Serieyssol, K.; Chatelard, S.; Cubizolle, H. Extraction, preparation and analysis of diatom fossils in mires. Mires Peat 2010, 7, 12.

63. Foster, D.R.; Fritz, S.C. Mire development, pool formation, and landscape processes of patterned fens in Dalarna, central Sweden. J. Ecol. 1987, 75, 409-437. [CrossRef]

64. Leira, M.; Bao, R.; Vidal-Romaní, J.R. Postglacial evolution of the Lake of Villaseca (NW Iberian Peninsula) inferred from diatom analysis. Cad. Lab. Xeol. 1997, 22, 81-97.

65. Leira, M. Diatom preservation in peat sediments. Cad. Lab. Xeol. Laxe 1998, 23, 225-236.

66. Bennett, P.C.; Melcer, M.E.; Siegel, D.I.; Hassett, J.P. The dissolution of quartz in dilute aqueous solutions of organic acids at $25^{\circ} \mathrm{C}$. Geochim. Cosmochim. Acta 1988, 52, 1521-1530. [CrossRef] 
67. Bennett, P.C.; Siegel, D.I.; Hill, B.M.; Glaser, P.H. Fate of silicate minerals in a peat bog. Geology 1991, 19, 328-331. [CrossRef]

68. Wheeler, B.D.; Proctor, C.F. Ecological gradients, subdivisions and terminology of north-west European mires. J. Ecol. 2000, 88, 187-203. [CrossRef]

69. Hájek, M.; Horsák, M.; Hájková, P.; Díte, D. Habitat diversity of central European fens in relation to environmental gradients and an effort to standardize fen terminology in ecological studies. Perspect. Plant Ecol. 2006, 8, 97-114. [CrossRef]

70. Bendell-Young, L. Peatland interstitial water chemistry in relation to that of surface pools along a peatland mineral gradient. Water Air Soil Poll. 2003, 143, 363-375. [CrossRef]

71. Patrick, S.; Holding, A.J. The effect of bacteria on the solubilization of silica in diatom frustules. J. Appl. Bacteriol. 1985, 59, 7-16. [CrossRef]

72. Bidle, K.D.; Azam, F. Accelerated dissolution of diatom silica by marine bacterial assemblages. Nature 1999, 397, 508-512. [CrossRef]

73. Bidle, K.D.; Azam, F. Bacterial control of silicon regeneration from diatom detritus: Significance of bacterial ectohydrolases and species identity. Limnol. Oceanogr. 2001, 46, 1606-1623. [CrossRef]

74. Myers-Smith, I.H.; Harden, J.W.; Wilmking, M.; Fuller, C.C.; McGuire, A.D.; Chapin, F.S., III. Wetland succession in a permafrost collapse: Interactions between fire and thermokarst. Biogeosciences 2008, 5, 1273-1286. [CrossRef]

75. Fritz, M.; Wolter, J.; Rudaya, N.; Palagushkina, O.; Nazarova, L.; Obu, J.; Rethemeyer, J.; Lantuit, H.; Wetterich, S. Holocene ice-wedge polygon development in northern Yukon permafrost peatlands (Canada). Quat. Sci. Rev. 2016, 147, 279-297. [CrossRef]

76. Rühland, K.; Smol, J.P.; Jasinski, J.P.P.; Warner, B.G. Response of diatoms and other siliceous indicators to the developmental history of a peatland in the Tiksi Forest, Siberia, Russia. Arct. Antarct. Alp. Res. 2000, 32, 167-178. [CrossRef]

77. Ma, L.; Gao, C.; Kattel, G.R.; Yu, X.; Wang, G. Evidence of Holocene water level changes inferred from diatoms and the evolution of the Honghe Peatland on the Sanjiang Plain of Northeast China. Quat. Int. 2018, 476, 82-94. [CrossRef]

78. Fukumoto, Y.; Kashima, K.; Orkhonselenge, A.; Ganzorig, U. Holocene environmental changes in northern Mongolia inferred from diatom and pollen records of peat sediment. Quat. Int. 2012, 254, 83-91. [CrossRef]

79. Korhola, A. Paleolimnology and hydroseral development of the Kotasuo bog, Southern Finland, with special reference to the Cladocera. Ann. Acad. Sci. Fenn. 1990, 155, 1-40.

80. Korhola, A. Mire induction, ecosystem dynamics and lateral extension on raised bog, southern coastal area of Finland. Fennia 1992, 170, 25-94.

81. Kokfelt, U.; Struyf, E.; Randsalu, L. Diatoms in peat-Dominant producers in a changing environment? Soil Biol. Biochem. 2009, 41, 1764-1766. [CrossRef]

82. Diot, M.F.; Baudrimont, R. Zonation paléoclimatique d'une tourbière de Charente: Étude des pollens et des diatomées. C. R. Acad. Sci. 1969, 269, 20-23. (In French)

83. Cubizolle, H.; Fassion, F.; Argant, J.; Latour-Argant, C.; Galet, P.; Oberlin, C. Mire initiation, climatic change and agricultural expansion over the course of the Late-Holocene in the Massif Central mountain range (France): Causal links and implications for mire conservation. Quat. Int. 2012, 251, 77-96. [CrossRef]

84. Cubizolle, H.; Haas, J.N.; Bielowski, W.; Dietre, B.; Argant, J.; Latour-Argant, C.; Chatelard, S.; Porteret, J.; Lefèvre, J.P. Palaeo-paludification, environmental change and human impact during the Mid- and Late Holocene in Western Europe: The example of the La Prenarde-Pifoy mire in the French Massif Central. Quaternaire 2013, 24, 419-422. [CrossRef]

85. Stancheva, R. Diatoms from Holocene sediments of Mt Sredna Gora. I. Phytol. Balc. 2001, 7, 85-101.

86. Stancheva, R. Diatoms from Holocene sediments of Mt Sredna Gora. II. Phytol. Balc. 2001, 7, 313-326.

87. Stancheva, R.; Temniskova, D. Paleoecology of Holocene diatoms from Sphagnum peat bogs in the Central Sredna Gora Mountains (Bulgaria). Geol. Carpath. 2004, 55, 65-76.

88. Gasse, F. Les diatomées Holocènes d'une Tourbière (4040 m) d'une Montagne Ethiopienne: Le Mont Badda. Rev. Algol. 1978, 13, 105-149. (In French)

89. Tanneberger, F.; Tegetmeyer, C.; Busse, S.; Barthelmes, A.; Shumka, S.; Moles-Mariné, A.; Jenderedjian, K.; Steiner, G.M.; Essl, F.; Etzold, J.; et al. The Peatland Map of Europe. Mires Peat 2017, 19, 1-17. 
90. Krauskopf, K.B. Dissolution and precipitation of silica at low temperatures. Geochim. Cosmochim. Acta 1956, 10, 1-26. [CrossRef]

91. Auer, V. Peat-bogs in southeastern Canada. Geol. Surv. Can. 1930, 62, 1-32.

92. Straub, F. Diatoms and their preservation in the sediments of Lake Neuchâtel (Switzerland) as evidence of past hydrological change. Hydrobiologia 1993, 269, 167-178. [CrossRef] 